Available online: https://journals.researchsynergypress.com/index.php/ijebce/

International Journal of Entrepreneurship, Business and Creative Economy (IJEBCE)

ISSN 2775-3085 (Online) | 2775-3107 (Print)

Volume 2 Number 1 (2022): 67-80

\title{
E-ServiceQuality Model and Kano Model: An Integration Improvement on Service Quality in E-Commerce Services
}

\author{
Krishna Kusumahadi ${ }^{1}$, Widya Sastika ${ }^{1}$, Fanni Husnul Hanifa ${ }^{1}$ \\ ${ }^{1}$ Fakultas Ekonomi Bisnis, Universitas Telkom, Indonesia
}

\begin{abstract}
Indonesia has become the largest e-commerce market in South East Asia. According to Wearesocial and Hootsuite data, around $90 \%$ of internet users in Indonesia have experienced online shopping. In 2019, the e-commerce market's capital value in Indonesia reached USD 21 Million or about Rp 294 trillion. Based on McKinsey Report, the e-commerce industry in Indonesia is predicted to reach USD 40 million in 2022. The increase of online shopping activity reached $400 \%$ during the 2020 pandemic, causing a $23.11 \%$ increase in e-commerce service complaints. This research is conducted for improvement in e-commerce's service quality by integrating the kano model and E-ServiceQuality model. Results obtained from customers' needs will be true customer needs able to be analysed for the purpose of increasing satisfaction. Attributes of needs obtained from the voice of the customer will be grouped into E-ServiceQuality dimensions, such as Efficiency, Fulfilment, Reliability, privacy, responsiveness, compensation, and contact. Afterward, these attributes of needs will generate strong attributes and weak attributes grouped into several categories, kept, developed, and ignored. Based on the research conducted among 400 respondents, the conclusions to answer problems according to problem formulation within this research are obtained. The result of this classification is True Customer Needs, where the seven attributes are recommended to be improved, and one attribute is recommended to be developed. The eight attributes which become True Customer Needs are Interaction Channel, Customer Service Responsiveness, Website Feature, Up to Date Information, 24hour Service, Quick Complaints Response, Cheap/Free Delivery Fee, and correct product guarantee.
\end{abstract}

Keywords: E-Service quality; Kano Model; E-commerce; Service Quality; True Customer Needs

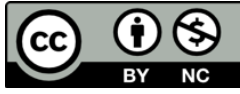

This is an open access article under the CC-BY-NC license.

\section{INTRODUCTION}

Online shopping behaviour has become the habit of many people, especially in the middle of the current pandemic. Moreover, Indonesia is Southeast Asia's largest e-commerce market. According to Wearesocial and Hootsuite data, around 90\% of Indonesia's internet users have experienced online shopping. In 2019, the capital value of the e-commerce market in Indonesia reached USD 21 million, or about Rp 294 trillion. Based on McKinsey Report, the e-commerce industry in Indonesia is predicted to reach USD 40 million in 2022. There are several factors that affect the rapid development of e-commerce in Indonesia (Sirclo.com, 2020).

IPrice, is one of the researchers and plays a role in mapping e-commerces in Southeast Asia comprised of Indonesia, Malaysia, Thailand, Singapore, Vietnam, and the Philippines. During Q2 2020, iPrice releases a list of e-commerce in Indonesia sorted by the average amount of visitors in each quarter. According to iPrice research, Shopee managed to occupy a rank in online shopping 
International Journal of Entrepreneurship, Business and Creative Economy (IJEBCE), Vol. 2(1), 67-80

E-ServiceQuality Model and Kano Model: An Integration Improvement on Service Quality in

E-Commerce Services

Krishna Kusumahadi, Widya Sastika, Fanni Husnul Hanifa

website with the highest amount of visitors monthly with a total of 93.440 .300 visitors per month (IPrice, 2020).
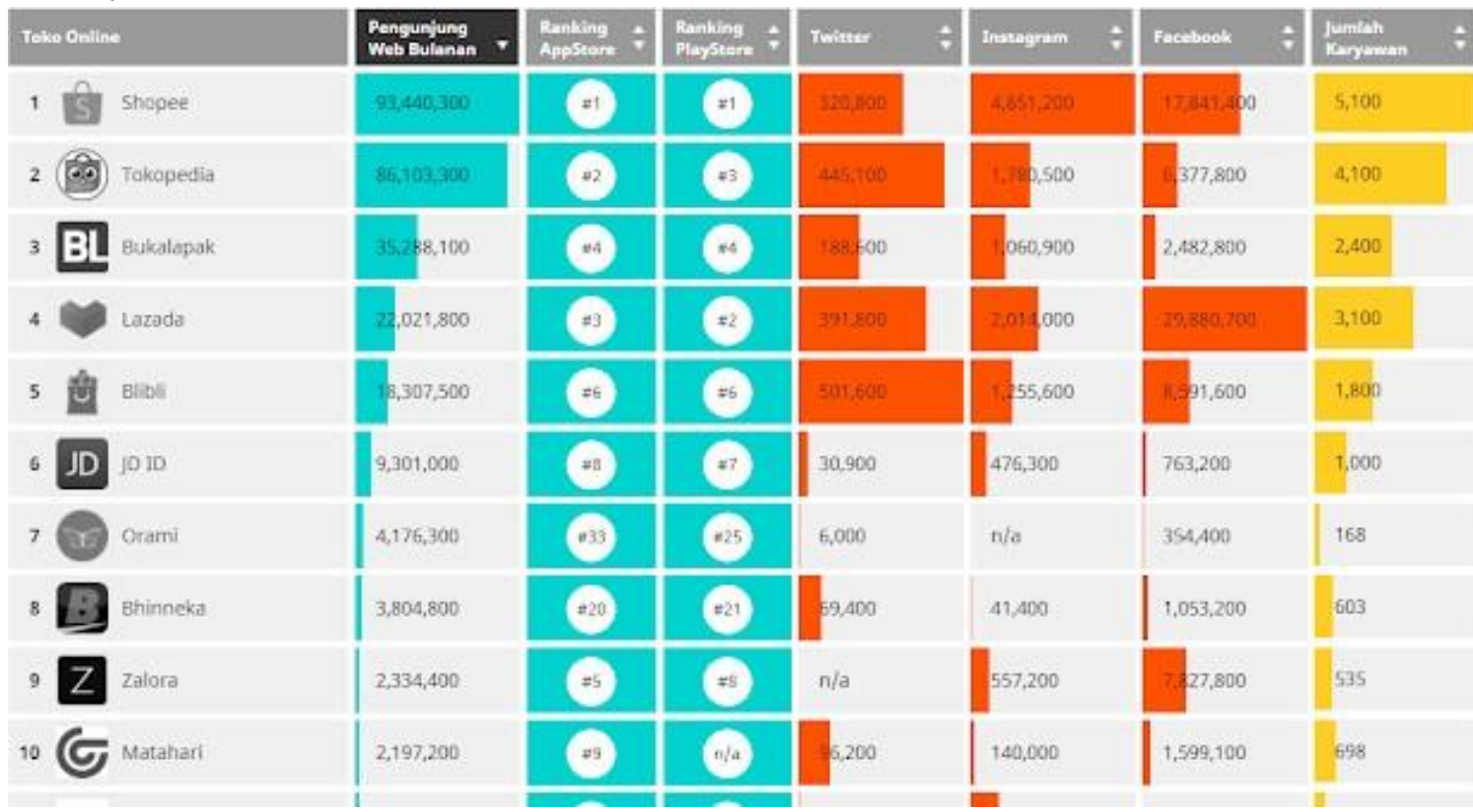

Figure 1. Websites Ranks 1-10, Online Stores \& E-Commerce Indonesia in 2020

[iprice.co.id;2020]

According to Analytic Data Advertising (ADA), online shopping activities increase 400\% during this pandemic. The Bank of Indonesia (BI) records procurement transactions through ecommerce in March 2020 reached 98,3 million transactions. The number increased 18.1\% compared to February. Moreover, the total value of the transaction in E-commerce in Indonesia has increased 9.9\% to Rp 20,7 trillion since February 2020. "In this digital era, people can easily do a virtual transaction in shopping, for example, cash on delivery (cod), e-wallet, joint account, transfer and credit card (Komalasari, 2020).

National Consumer Protection Agency (BPKN) reports a spike in the number of complaints from e-commerce users in 2020. "E-commerce experience rapid improvement during 2020. "In the last three years, there are only 1,35\% [from total complaints], and in 2020 the complaints increase 23.11\%, out of 295 complaints received, national Consumer Protection agency records 94 cases were processed and ended up with the fulfillment of customer's right. Meanwhile, there are 201 cases left that are still in the process of handling" (karirbisnis.com, 2020).

The customer's complaints are refund problems, phishing with the takeover of One Time Password (OTP), the purchase of a faulty product, unreceived cashback, unusable voucher, unfulfilled guarantee, and many others (BKPN, 2020).

National Consumer Protection Agency states the high number of complaints could be caused by the higher number of consumers who do online transactions ever since the Covid-19 pandemic spreads in Indonesia. Government policy about large-scale social restriction (PSBB) applied in various regions changes the pattern of people's consumption which causes the value of e-commerce transactions to increase drastically (Komalasari, 2020). According to National Consumer Protection Agency, the increase in customer complaints related to e-commerce platforms needs to receive 
International Journal of Entrepreneurship, Business and Creative Economy (IJEBCE), Vol. 2(1), 67-80

E-ServiceQuality Model and Kano Model: An Integration Improvement on Service Quality in

E-Commerce Services

Krishna Kusumahadi, Widya Sastika, Fanni Husnul Hanifa

special attention. "If the transaction in e- commerce's platform is not safe, the consequence is the decrease of the transaction value." (Indonesia.go.id, 2020).

\section{LITERATURE REVIEW}

\section{E-ServiceQuality}

E-ServiceQuality is the most comprehensive and integrative model of online service quality. Moreover, E-ServiceQuality is an overall valuation and evaluation of the advantages of an electronic service within an online or virtual market (Tjiptono et al., 2016). E-ServiceQuality, which is known as E-ServQual, is the newest version of Service Quality (ServQual). E-ServQual is developed to evaluate a service given within the internet. Seeing that the dimensions stated by Zeithaml et al. are relevant and fulfill the need to evaluate electronic service quality thoroughly. It can be said that EServiceQuality is an overall valuation and evaluation of the advantages of electronic service delivery in a virtual market.

There are 7 dimensions in E-ServiceQuality concisely explained as follow (Tjiptono et al., 2016):

A. Efficiency is the customer's ability to access a website, search for a wanted product or service and information related to the product or service, and also leave the website with minimum maintenance.

B. Fulfilment is comprised of service promise accuracy, the availability of a product or service feature, and also the delivery of a product within the promised period.

C. Reliability refers to the technical functionality of a website, especially to what extent a website is available and functions as it should be.

D. Privacy is a guarantee that the information and the safety of customers' private data or account are secured and protected.

E. Responsiveness is effective handling of customers' complaints. A quick service can give the customer more sense of security during online purchases.

F. Compensation comprised of return, reward or commission, delivery fee, product handling fee, or also user account handling fee within the application et cetera.

G. Contact reflects the customer's need to be able to communicate with customer service staff either online or through phone calls (and not communicate with a machine).

\section{Kano Model}

Kano model was developed by noriaki kano in 1984; kano model is used to measure to what extent a service function can fulfill customer's needs and wishes (Tan \& Pawitra, 2001); according to Kano, customer needs are divided into three kinds, Must-be (basic needs), one dimensional (performance needs) and attractive (excitement needs).

\section{Must-be Category}

The customer regards the attributes in this category as a must within service delivery. If these attributes are fulfilled, it will not significantly affect the improvement of customer satisfaction; on the other hand, if these attributes aren't fulfilled, customer satisfaction will decrease.

\section{One-dimensional Category}

Customer satisfaction will increase if the attributes within this category are fulfilled; on the other hand, if the attributes aren't fulfilled, customer satisfaction will decrease. 
International Journal of Entrepreneurship, Business and Creative Economy (IJEBCE), Vol. 2(1), 67-80

E-ServiceQuality Model and Kano Model: An Integration Improvement on Service Quality in

E-Commerce Services

Krishna Kusumahadi, Widya Sastika, Fanni Husnul Hanifa

\section{Attractive Category}

The customer will be satisfied if the attributes in this category are fulfilled, but the customer will not be disappointed if the attributes in this category aren't fulfilled. The level of customer satisfaction will rise greatly along with the increase of attributes performance, but the decrease of attribute performance will not cause a decline in the level of satisfaction.

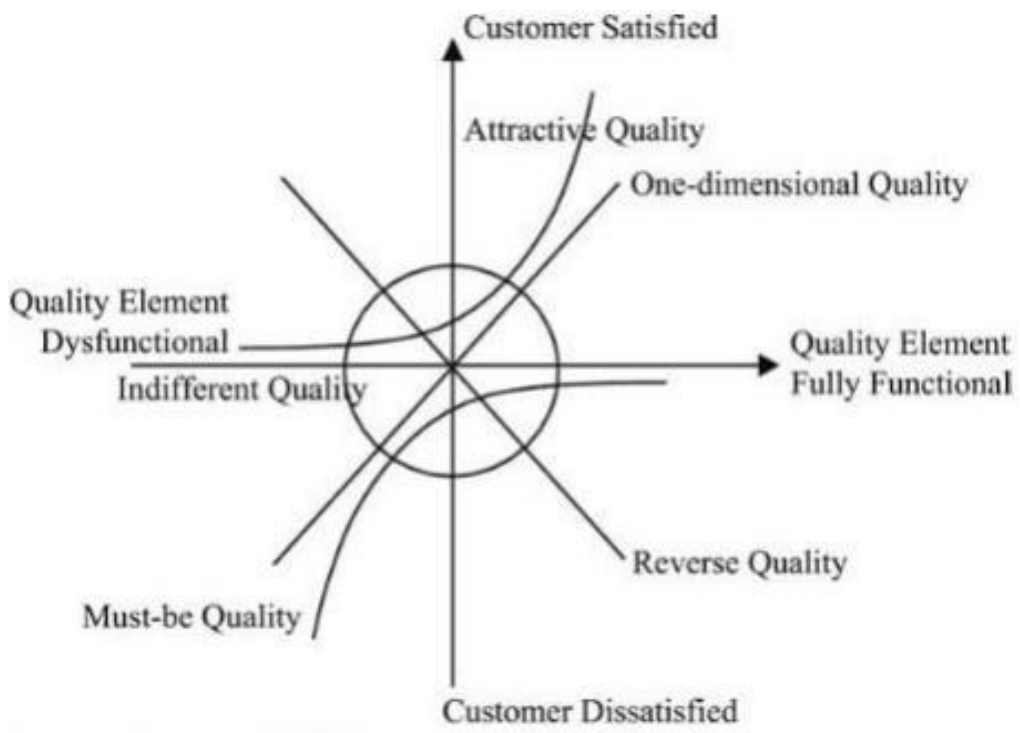

Figure 2. Model Kano (Kano et al, 1984 in Lee, Lin \& Wang, 2011)

There are two kinds of questionnaires used to identify customers' opinions, such as functional, which consists of questions regarding attributes given and how it relates to what the customer feels, and dysfunctional, which consists of questions regarding if attributes aren't given and how it relates with what the customer feels. These two questions are classified into six kano categories, such as $\mathrm{A}=$ Attractive, $\mathrm{M}=$ Must $\mathrm{Be}, \mathrm{O}=$ One Dimensional, $\mathrm{I}=$ Indifferent, $\mathrm{R}=$ Reverse dan $\mathrm{Q}=\mathrm{Questionable}$. Kano category is classified into kano model diagram, which can be seen in figure 2 (Lee \& Wang, 2011).

In addition to the three basic kano models, there are also other categories such as indifferent, reverse, and questionable (Mikulic \& Prebezac, 2011). The explanations of the three attributes are as follow:

1. Indifferent Category. Prohibition for customers to show their needs. This category can be judged as a neutral category and will not affect customer satisfaction and dissatisfaction when made available.

2. Questionable Category. Questionable Category is an attribute of need that identifies misunderstanding and confusion within questions and answers were given; making customer needs cannot be translated clearly in this category.

3. Reverse Category. The customer is dissatisfied due to the existence of attributes in this category, but the customer will be satisfied if the attributes in this category do not exist. 
International Journal of Entrepreneurship, Business and Creative Economy (IJEBCE), Vol. 2(1), 67-80

E-ServiceQuality Model and Kano Model: An Integration Improvement on Service Quality in

E-Commerce Services

Krishna Kusumahadi, Widya Sastika, Fanni Husnul Hanifa

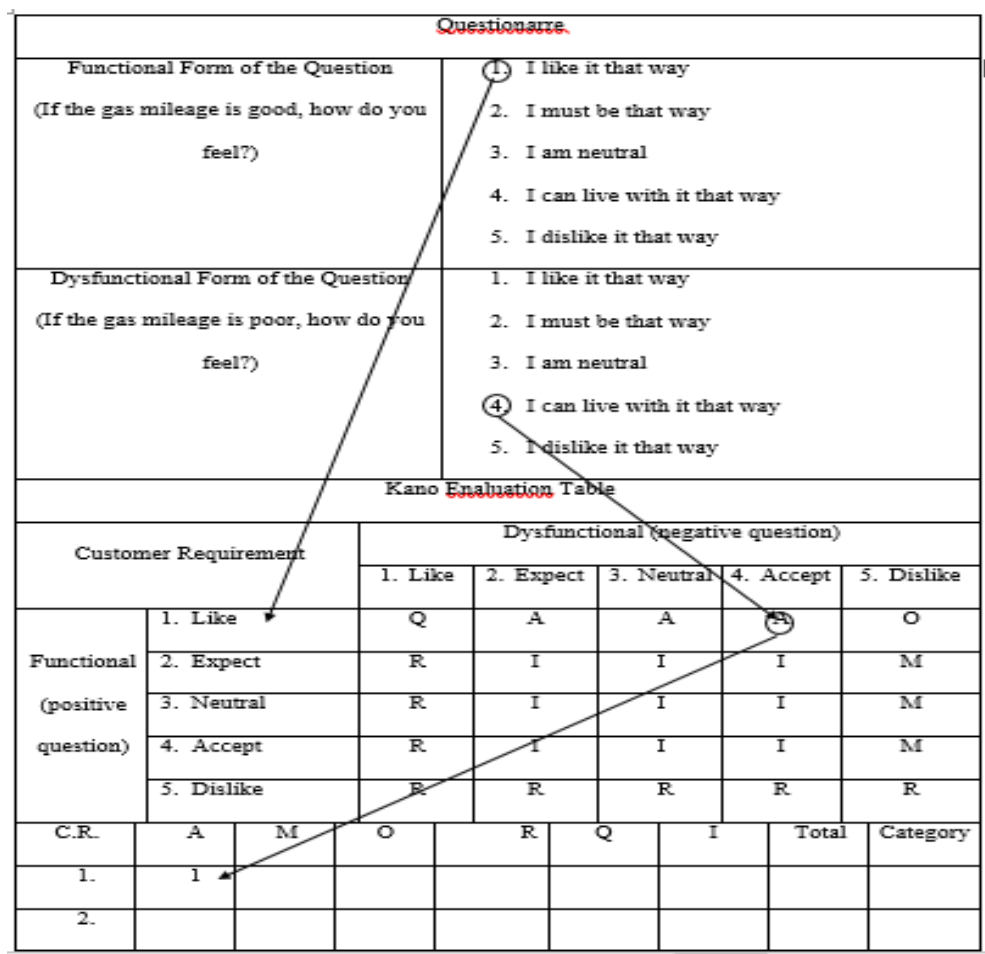

Information: $\mathrm{A}=$ Attractive, $\mathrm{O}=$ One Dimensional, $\mathrm{M}=$ Must $\mathrm{Be}, \mathrm{Q}=$ Questionable, $\mathrm{R}=$ Reverse, $\mathrm{I}=$ Indifferent.

Figure 3. Blauth's Formula [Kano et al., 1984 in Mikulic dan Prebezac,2011]

\section{The Integration of E-ServiceQuality and Kano Model}

The integration between E-ServiceQuality and Kano model is able to cover each other's flaws and also to give a better solution to a problem. Kano model categorizes the attributes of service needs while E-ServiceQuality categorizes weak and strong attributes (Tan \& Pawitra, 2001). Figure 4 is the framework of E-ServiceQuality and kano model integration.

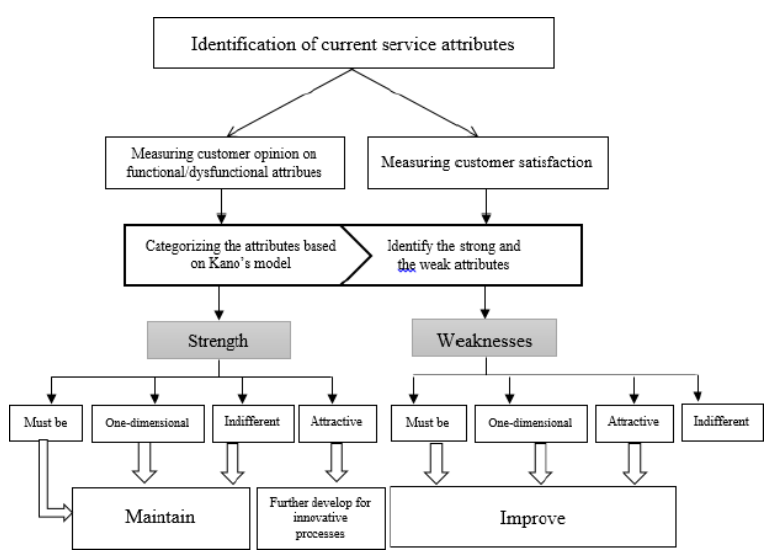

Figure 4. Integration E-ServiceQuality dan Kano Model (Tan \& Pawitra, 2001) 
International Journal of Entrepreneurship, Business and Creative Economy (IJEBCE), Vol. 2(1), 67-80

E-ServiceQuality Model and Kano Model: An Integration Improvement on Service Quality in

E-Commerce Services

Krishna Kusumahadi, Widya Sastika, Fanni Husnul Hanifa

\section{RESEARCH METHOD}

The conceptual model is used to illustrate the structured design, which connects concept and indicate the purpose of research in order to find out a solution to the problem. The framework model in this research will be explained in the following figure 5 .

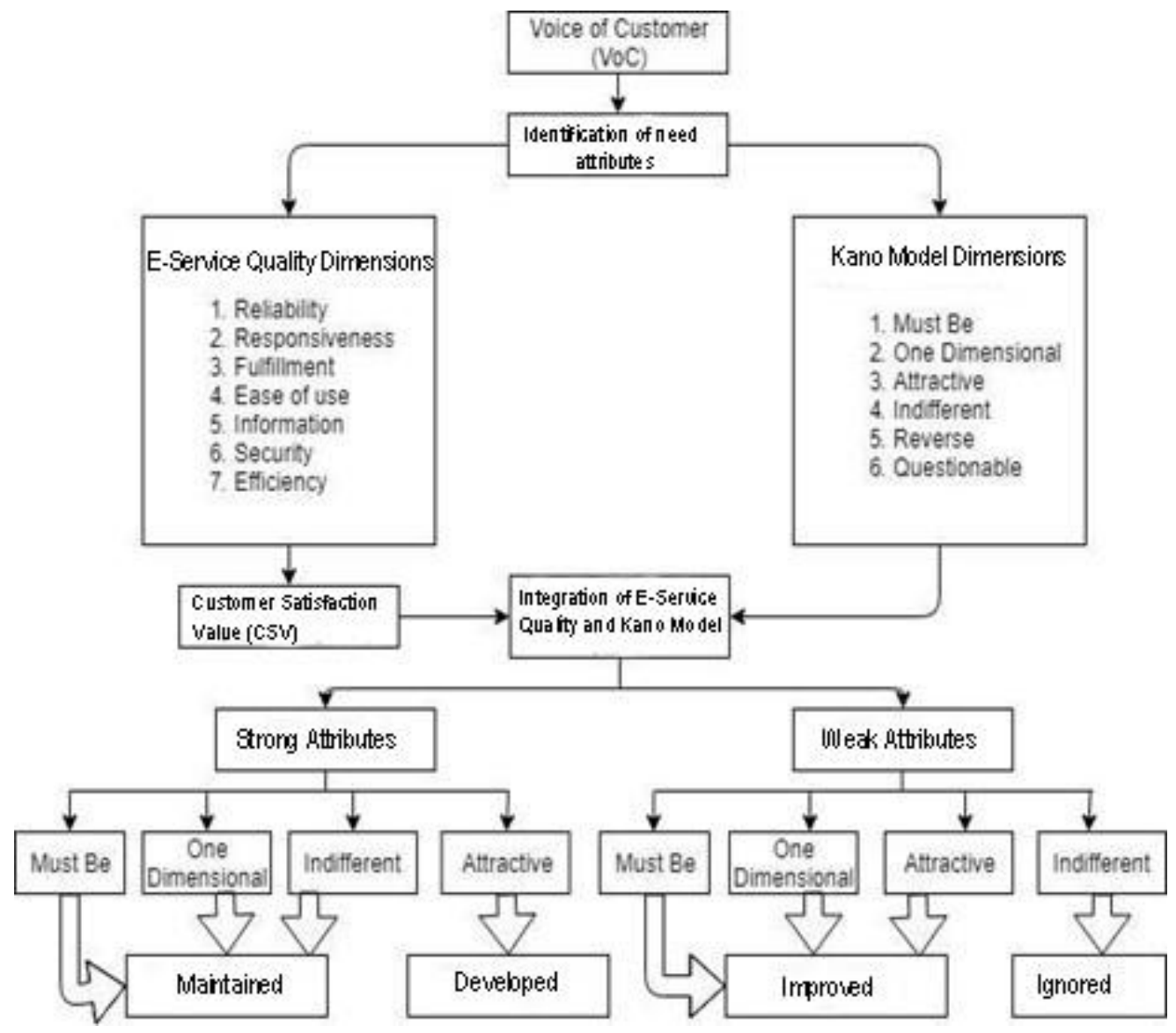

Figure 5. Conceptual Model

The model above is a general illustration of the integration of the Kano and E-ServiceQuality model. The result obtained from customer needs will be true customer needs that can be analysed to improve customer satisfaction. Attributes of needs obtained through the voice of the customer will be grouped into E-ServiceQuality dimensions such as efficiency, fulfillment, reliability, privacy, responsiveness, compensation, and contact. Afterward, the said attributes of needs will generate strong and weak attributes, which are classified into several categories, such as kept, developed, and ignored. The result obtained from the classification is true customer needs.

\section{FINDINGS AND DISCUSSION}

\section{Attributes of Needs Identification}

Identification of attributes of needs is the initial stage of data collection that aims to determine the wants and needs of e-commerce customers. The identification of the attributes of 
International Journal of Entrepreneurship, Business and Creative Economy (IJEBCE), Vol. 2(1), 67-80

E-ServiceQuality Model and Kano Model: An Integration Improvement on Service Quality in

E-Commerce Services

Krishna Kusumahadi, Widya Sastika, Fanni Husnul Hanifa

needs is made by using interviews and literature studies. Interviews will produce attributes of needs that are sourced from Voice of Customer, and literature study will produce attributes that are sourced from relevant previous research.

The required attributes obtained will be grouped with the selected electronic service quality dimensions based on previous research. The selected dimensions are Efficiency, Fulfillment, Reliability, Privacy, Responsiveness, Compensation, and Contact can be seen in Table 1 below.

Table 1. Attributes of Needs and Dimensions of Electronic Service Quality

\begin{tabular}{|c|c|c|c|}
\hline Dimensions & No & Attributes of Needs Results & Code \\
\hline \multirow{3}{*}{ Efficiency } & 1 & Various features available on the website & EF1 \\
\hline & 2 & Easy ordering process on product & EF2 \\
\hline & 3 & The menu can be found easily & EF3 \\
\hline \multirow{3}{*}{ Fulfilment } & 4 & $\begin{array}{l}\text { Complete product information (price, material, size chart, et } \\
\text { cetera.) }\end{array}$ & FL1 \\
\hline & 5 & $\begin{array}{l}\text { Up to date information on the website (products, prices, } \\
\text { promotions, et cetera.) }\end{array}$ & FL2 \\
\hline & 6 & The information presented is clear (unambiguous) & FL3 \\
\hline \multirow{3}{*}{ Reliability } & 7 & Website is easy to access & RL1 \\
\hline & 8 & Product suitability description on the website & RL2 \\
\hline & 9 & On-Time Delivery & RL3 \\
\hline \multirow{3}{*}{ Privacy } & 10 & Safe product ordering process & PC1 \\
\hline & 11 & Securely Data Account & PC2 \\
\hline & 12 & Products Purchase Guarantee & PC3 \\
\hline \multirow{3}{*}{$\begin{array}{l}\text { Responsiven } \\
\text { ess }\end{array}$} & 13 & $\begin{array}{l}\text { Interaction channels (chat boxes, et cetera.) between customers } \\
\text { and customer service }\end{array}$ & RS1 \\
\hline & 14 & Customer Service Fast Respond & RS2 \\
\hline & 15 & Customer Service Complaint Handler & RS3 \\
\hline \multirow{3}{*}{$\begin{array}{l}\text { Compensati } \\
\text { on }\end{array}$} & 16 & Easy Return on Product & CM1 \\
\hline & 17 & Customers promotions or points & CM2 \\
\hline & 18 & Affordable or free shipping & CM3 \\
\hline \multirow{3}{*}{ Contact } & 19 & 24/7 Customer Service & CT1 \\
\hline & 20 & Fast Respond on Compaints & CT2 \\
\hline & 21 & Easy Access on 24/7 Customer Service & СT3 \\
\hline
\end{tabular}

\section{E-ServiceQuality Questionnaire Data Processing}

The electronic service quality questionnaire was used to measure the Customer Satisfaction Value (CSV); based on the results of the electronic service quality questionnaire data processing in Table 2 , there are attributes that go into the category of strong and weak attributes. The resulting strong and weak attributes are defined as follows:

1. Strong Attributes

Attributes that are categorized as strong attributes are attributes with CSV positive value, where e-commerce services have met consumer expectations. Based on the results of the 
International Journal of Entrepreneurship, Business and Creative Economy (IJEBCE), Vol. 2(1), 67-80

E-ServiceQuality Model and Kano Model: An Integration Improvement on Service Quality in

E-Commerce Services

Krishna Kusumahadi, Widya Sastika, Fanni Husnul Hanifa

electronic service quality questionnaire data processing, there are 14 attributes that are included in the strong attributes, which are listed in Table 2 below.

Table 2. Strong Attributes of E-ServiceQuality

\begin{tabular}{|l|l|l|l|l|l|l|l|}
\hline No & Code & Expectancy & Reality & GAP & Importance & CSV & Explanation \\
\hline 1 & RL1 & 3,47 & 3,55 & 0,08 & 3,88 & 0,30 & Strong \\
\hline 2 & RL2 & 3,41 & 3,55 & 0,14 & 3,45 & 0,48 & Strong \\
\hline 3 & RL3 & 3,36 & 3,44 & 0,08 & 3,05 & 0,23 & Strong \\
\hline 4 & RS3 & 3,43 & 3,52 & 0,09 & 3,03 & 0,26 & Strong \\
\hline 5 & EF2 & 3,43 & 3,49 & 0,06 & 3,02 & 0,19 & Strong \\
\hline 6 & EF3 & 3,24 & 3,42 & 0,18 & 3,10 & 0,57 & Strong \\
\hline 7 & FL1 & 3,36 & 3,42 & 0,06 & 3,34 & 0,20 & Strong \\
\hline 8 & FL3 & 3,48 & 3,55 & 0,08 & 3,35 & 0,26 & Strong \\
\hline 9 & CT1 & 3,46 & 3,55 & 0,09 & 3,01 & 0,27 & Strong \\
\hline 10 & CT3 & 3,32 & 3,47 & 0,15 & 3,28 & 0,47 & Strong \\
\hline 11 & CM1 & 3,40 & 3,47 & 0,08 & 3,25 & 0,24 & Strong \\
\hline 12 & CM3 & 3,41 & 3,49 & 0,09 & 3,80 & 0,32 & Strong \\
\hline 13 & PC1 & 3,49 & 3,80 & 0,31 & 3,00 & 0,92 & Strong \\
\hline 14 & PC2 & 3,47 & 3,63 & 0,16 & 3,49 & 0,55 & Strong \\
\hline
\end{tabular}

2. Weak Attribute

Attributes that are categorized as weak attributes are attributes with negative CSV value, where e- commerce services have not met consumer expectations. Based on the results of the electronic service quality questionnaire data processing, there are 7 attributes that are included in the weak attributes, which are listed in Table 3 below.

Table 3. Weak Attributes of E-ServiceQuality

\begin{tabular}{|l|l|l|l|l|l|l|l|}
\hline No & Code & Expectancy & Reality & GAP & Importance & CSV & Explanation \\
\hline 1 & RS1 & 3,26 & 3,03 & $-0,23$ & 3,16 & $-0,73$ & Weak \\
\hline 2 & RS2 & 3,47 & 3,28 & $-0,19$ & 3,29 & $-0,62$ & Weak \\
\hline 3 & EF1 & 3,39 & 3,08 & $-0,31$ & 3,61 & $-1,12$ & Weak \\
\hline 4 & FL2 & 3,38 & 3,17 & $-0,22$ & 2,98 & $-0,64$ & Weak \\
\hline 5 & CT2 & 3,39 & 3,12 & $-0,27$ & 3,10 & $-0,84$ & Weak \\
\hline 6 & CM2 & 3,57 & 3,45 & $-0,12$ & 3,64 & $-0,45$ & Weak \\
\hline 7 & PC3 & 3,51 & 3,21 & $-0,30$ & 3,10 & $-0,94$ & Weak \\
\hline
\end{tabular}

\section{Kano Model Questionnaire Data Processing}

The data obtained from the Kano model questionnaire, which are functional and dysfunctional, were first converted into the Kano category using Blauth's Formula. Each attribute is identified by category that is Must be (M), One dimensional (O), Attractive (A), Indifferent (I), Reverse (R), and Questionable (Q). Kano model categories can be seen in Table 4 below. 
International Journal of Entrepreneurship, Business and Creative Economy (IJEBCE), Vol. 2(1), 67-80

E-ServiceQuality Model and Kano Model: An Integration Improvement on Service Quality in

E-Commerce Services

Krishna Kusumahadi, Widya Sastika, Fanni Husnul Hanifa

Table 4. KANO Model Questionnaire Data Processing

\begin{tabular}{|l|l|l|l|l|l|l|l|l|l|l|}
\hline No & Code & A & $\mathbf{0}$ & $\mathbf{M}$ & $\mathbf{A + 0 + M}$ & $\mathbf{I}$ & $\mathbf{R}$ & $\mathbf{Q}$ & $\mathbf{I + R + Q}$ & Kano Category \\
\hline 1 & RL1 & 80 & 91 & 155 & $\mathbf{3 2 6}$ & 74 & 0 & 0 & $\mathbf{7 4}$ & M \\
\hline 2 & RL2 & 114 & 111 & 123 & $\mathbf{3 4 8}$ & 52 & 0 & 0 & $\mathbf{5 2}$ & M \\
\hline 3 & RL3 & 89 & 125 & 121 & $\mathbf{3 3 5}$ & 24 & 0 & 0 & $\mathbf{6 5}$ & 0 \\
\hline 4 & RS1 & 113 & 104 & 108 & $\mathbf{3 2 5}$ & 75 & 0 & 0 & $\mathbf{7 5}$ & A \\
\hline 5 & RS2 & 98 & 135 & 106 & $\mathbf{3 3 9}$ & 61 & 0 & 0 & $\mathbf{6 1}$ & 0 \\
\hline 6 & RS3 & 77 & 139 & 113 & $\mathbf{3 2 9}$ & 71 & 0 & 0 & $\mathbf{7 1}$ & 0 \\
\hline 7 & EF1 & 105 & 95 & 98 & $\mathbf{2 9 8}$ & 102 & 0 & 0 & $\mathbf{1 0 2}$ & A \\
\hline 8 & EF2 & 95 & 110 & 95 & $\mathbf{3 0 0}$ & 100 & 0 & 0 & $\mathbf{1 0 0}$ & 0 \\
\hline 9 & EF3 & 95 & 118 & 98 & $\mathbf{3 1 1}$ & 89 & 0 & 0 & $\mathbf{8 9}$ & 0 \\
\hline 10 & FL1 & 87 & 42 & 182 & $\mathbf{3 1 1}$ & 89 & 0 & 0 & $\mathbf{8 9}$ & M \\
\hline 11 & FL2 & 39 & 85 & 189 & $\mathbf{3 1 3}$ & 87 & 0 & 0 & $\mathbf{8 7}$ & M \\
\hline 12 & FL3 & 47 & 49 & 179 & $\mathbf{2 7 5}$ & 125 & 0 & 0 & $\mathbf{1 2 5}$ & M \\
\hline 13 & CT1 & 90 & 108 & 102 & $\mathbf{3 0 0}$ & 100 & 0 & 0 & $\mathbf{1 0 0}$ & 0 \\
\hline 14 & CT2 & 102 & 149 & 79 & $\mathbf{3 3 0}$ & 70 & 0 & 0 & $\mathbf{7 0}$ & 0 \\
\hline 15 & CT3 & 50 & 152 & 50 & $\mathbf{2 5 2}$ & 148 & 0 & 0 & $\mathbf{1 4 8}$ & 0 \\
\hline 16 & CM1 & 67 & 158 & 72 & $\mathbf{2 9 7}$ & 103 & 0 & 0 & $\mathbf{1 0 3}$ & 0 \\
\hline 17 & CM2 & 99 & 89 & 99 & $\mathbf{2 8 7}$ & 113 & 0 & 0 & $\mathbf{1 1 3}$ & I \\
\hline 18 & CM3 & 125 & 78 & 103 & $\mathbf{3 0 6}$ & 94 & 0 & 0 & $\mathbf{9 4}$ & A \\
\hline 19 & PC1 & 89 & 98 & 143 & $\mathbf{3 3 0}$ & 70 & 0 & 0 & $\mathbf{7 0}$ & M \\
\hline 20 & PC2 & 109 & 82 & 119 & $\mathbf{3 1 0}$ & 90 & 0 & 0 & $\mathbf{9 0}$ & M \\
\hline 21 & PC3 & 91 & 89 & 121 & $\mathbf{3 0 1}$ & 99 & 0 & 0 & $\mathbf{9 9}$ & M \\
\hline & & & & & & & & & \\
\hline
\end{tabular}

Based on Kano's questionnaire data processing, the attribute categories of Must be (M), One dimensional (O), Attractive (A), Indifferent (I), Reverse (R), Questionable (Q) were obtained based on the calculation of functional and dysfunctional statements. After processing the Kano model questionnaire data, there were only four Kano categories, that is Must be (M), One dimensional (O), Attractive (A), and Indifferent (I). The explanations for the four categories are as follows:

1. Must Be Category (M)

Must be (M) attributes category are attributes that must exist in e-commerce services because if these attributes are not met, they will have an effect on customer satisfaction, but if these attributes are met, it will not have much effect on customer satisfaction of ecommerce users. So it can be interpreted that the must-be (M) category attributes are basic customer needs that must be met by e-commerce parties. Based on the data processing of the Kano model questionnaire, the attributes that are included in the must be category are 8 attributes which can be seen in Table 5 below.

Table 5. Must Be (M) Category Attribute

\begin{tabular}{|l|c|lc|}
\hline No & Attribute Code & & Attribute Necessity \\
\hline 1 & RL1 & Easy Access Website \\
\hline
\end{tabular}


International Journal of Entrepreneurship, Business and Creative Economy (IJEBCE), Vol. 2(1), 67-80

E-ServiceQuality Model and Kano Model: An Integration Improvement on Service Quality in

E-Commerce Services

Krishna Kusumahadi, Widya Sastika, Fanni Husnul Hanifa

\begin{tabular}{|l|l|l|}
\hline 2 & RL2 & Product suitability description on the website \\
\hline 3 & FL1 & Complete product information (price, material, size chart, et cetera.) \\
\hline 4 & FL2 & $\begin{array}{l}\text { Up to date information on the website (products, prices, promotions, et } \\
\text { cetera.) }\end{array}$ \\
\hline 5 & FL3 & The information presented is clear (unambiguous) \\
\hline 6 & PC1 & Safe product ordering process \\
\hline 7 & PC2 & Securely Data Account \\
\hline 8 & PC3 & Guarantee the purchase of products \\
\hline
\end{tabular}

2. One Dimensional Category (0)

One Dimensional $(0)$ attributes category is attributes that will affect customer satisfaction. When this attribute is met, then it will increase customer satisfaction; when this attribute is not met, then customer satisfaction will decrease. Based on the processing of the Kano model, the attributes included in the one-dimensional (0) category are 9 attributes and can be seen in Table 6 below.

Table 6. One Dimensional Category Attribute

\begin{tabular}{|c|c|l|}
\hline No & Attribute Code & \multicolumn{1}{|c|}{ Attribute Necessity } \\
\hline 1 & RL3 & On-Time Delivery \\
\hline 2 & RS2 & Customer Service Fast Respond \\
\hline 3 & RS3 & Customer Service Complaint Handler \\
\hline 4 & EF2 & Easy ordering process on product \\
\hline 5 & EF3 & Menu can be found easily \\
\hline 6 & CT1 & $24 / 7$ Customer Service \\
\hline 7 & CT2 & Fast Respond on Compaints \\
\hline 8 & CT3 & Easy Access on 24/7 Customer Service \\
\hline 9 & CM1 & Easy Return on Product \\
\hline
\end{tabular}

3. Attractive Category (A)

Attractive (A) attributes category are attributes that will increase customer satisfaction if these attributes are met but will not affect customer satisfaction if these attributes are not met. Based on the Kano model questionnaire processing, the attributes that fall into the attractive category are 3 attributes which can be seen in Table 7 below.

Table 7. Attractive Category Attribute

\begin{tabular}{|c|c|l|}
\hline No & Attribute Code & \multicolumn{1}{|c|}{ Attribute Necessity } \\
\hline 1 & RS1 & $\begin{array}{l}\text { Interaction channels (chat boxes, et cetera.) between customers and } \\
\text { customer service }\end{array}$ \\
\hline 2 & EF1 & Various features available on the website \\
\hline
\end{tabular}


International Journal of Entrepreneurship, Business and Creative Economy (IJEBCE), Vol. 2(1), 67-80

E-ServiceQuality Model and Kano Model: An Integration Improvement on Service Quality in

E-Commerce Services

Krishna Kusumahadi, Widya Sastika, Fanni Husnul Hanifa

4. Indifferent Category (I)

Indifferent (I) attributes category will not have an effect on customer satisfaction. Based on the Kano model questionnaire data processing, the attributes included into the indifferent category are one attribute which can be seen in Table 8 below.

Tabel 8. Indifferent Category Attribute

\begin{tabular}{|l|l|l|}
\hline No & Attribute Code & \multicolumn{1}{c|}{ Attribute Necessity } \\
\hline 1 & CM2 & Customers promotions or points \\
\hline
\end{tabular}

\section{Electronic Service Quality dan KANO Model Integration}

At this phase, the integration of the results of processing the thee-servqual questionnaire and the Kano model is carried out with the purpose of knowing which attributes must be maintained, improved \& developed.

Table 9. Electronics Service Quality and Kano Model Integration

\begin{tabular}{|l|l|l|l|l|l|}
\hline No & Attribute Code & CSV & E-Servqual Category & Kano Category & Recommendation \\
\hline 1 & RL1 & 0,30 & Strong & M & Maintain \\
\hline 2 & RL2 & 0,48 & Strong & M & Maintain \\
\hline 3 & RL3 & 0,23 & Strong & O & Maintain \\
\hline 4 & RS1 & $-0,73$ & Weak & A & Upgrade \\
\hline 5 & RS2 & $-0,62$ & Weak & 0 & Upgrade \\
\hline 6 & RS3 & 0,26 & Strong & 0 & Maintain \\
\hline 7 & EF1 & $-1,12$ & Weak & A & Upgrade \\
\hline 8 & EF2 & 0,19 & Strong & 0 & Maintain \\
\hline 9 & EF3 & 0,57 & Strong & 0 & Maintain \\
\hline 10 & FL1 & 0,20 & Strong & M & Maintain \\
\hline 11 & FL2 & $-0,64$ & Weak & M & Upgrade \\
\hline 12 & FL3 & 0,26 & Strong & M & Maintain \\
\hline 13 & CT1 & -0.45 & Weak & 0 & Upgrade \\
\hline 14 & CT2 & $-0,84$ & Weak & 0 & Upgrade \\
\hline 15 & CT3 & 0,47 & Strong & 0 & Maintain \\
\hline 16 & CM1 & 0,24 & Strong & 0 & Maintain \\
\hline 17 & CM2 & 0,27 & Strong & I & Maintain \\
\hline 18 & CM3 & 0,32 & Strong & A & Develop \\
\hline 19 & PC1 & 0,92 & Strong & M & Maintain \\
\hline 20 & PC2 & 0,55 & Strong & M & Maintain \\
\hline 21 & PC3 & $-0,94$ & Weak & M & Upgrade \\
\hline
\end{tabular}

The recommendation in the Table 9 column will determine the follow-up for each attribute. Weak attributes with Kano Must be (M), One dimensional (O), and Attractive (A) categories will be increased, strong attributes with Kano Attractive (A) categories will be developed, strong attributes with Kano Must be (M), One Dimensional (O) and Indifferent (I) categories will be maintained, weak attributes with Indifferent (I) categories will be ignored. Attributes with developed and improved 
International Journal of Entrepreneurship, Business and Creative Economy (IJEBCE), Vol. 2(1), 67-80

E-ServiceQuality Model and Kano Model: An Integration Improvement on Service Quality in

E-Commerce Services

Krishna Kusumahadi, Widya Sastika, Fanni Husnul Hanifa

recommendations are True Customer Needs (TCN). The attributes that make up the TCN can be seen in Table 10 below.

Tabel 10. True Customer Needs

\begin{tabular}{|l|l|l|l|l|l|}
\hline No & Attribute Code & CSV & E-Servqual Category & Kano Category & Recommendation \\
\hline 1 & RS1 & $-0,73$ & Weak & A & Upgrade \\
\hline 2 & RS2 & $-0,62$ & Weak & O & Upgrade \\
\hline 3 & EF1 & $-1,12$ & Weak & A & Upgrade \\
\hline 4 & FL2 & $-0,64$ & Weak & M & Upgrade \\
\hline 5 & CT2 & $-0,84$ & Weak & 0 & Upgrade \\
\hline 6 & CT1 & $-0,45$ & Weak & 0 & Upgrade \\
\hline 7 & CM3 & 0,32 & Strong & A & Develop \\
\hline 8 & PC3 & $-0,94$ & Weak & M & Upgrade \\
\hline
\end{tabular}

\section{True Customer Needs Recommendation}

Based on Table 10, there are 8 chosen attributes that will become true customer needs which consist of 7 attributes of needs that are improved and 1 attribute of needs that is developed. The following are explanations from each of the true customer needs. The following are a summary of recommendations in order to give solutions to this research and act as a reference for the reader, e-commerce owner, and further researchers.

Table 11. True Customer Needs Recommendation

\begin{tabular}{|c|c|c|c|c|c|c|}
\hline No & $\begin{array}{l}\text { True } \\
\text { Customer } \\
\text { Needs }\end{array}$ & Code & CSV & $\begin{array}{l}\text { Kano } \\
\text { Category }\end{array}$ & Action & Recommendation \\
\hline 1 & $\begin{array}{l}\text { Various } \\
\text { Interaction } \\
\text { channels } \\
\text { (chatbox,etc) } \\
\text { between } \\
\text { customer and } \\
\text { customer } \\
\text { service }\end{array}$ & RS1 & $-0,73$ & A & Improved & $\begin{array}{l}\text { Adding another interaction } \\
\text { channel in a website such as } \\
\text { chat service through } \\
\text { WhatsApp, Line, Facebook, } \\
\text { or other social media. }\end{array}$ \\
\hline 2 & $\begin{array}{l}\text { Quick } \\
\text { Response to } \\
\text { customer's } \\
\text { questions by } \\
\text { Customer } \\
\text { service }\end{array}$ & RS2 & $-0,62$ & 0 & Improved & $\begin{array}{l}\text { Using auto-reply to answer } \\
\text { frequently asked questions } \\
\text { by customers increases } \\
\text { employees in the customer } \\
\text { service section. }\end{array}$ \\
\hline 3 & $\begin{array}{l}\text { Various } \\
\text { features } \\
\text { available on } \\
\text { the website }\end{array}$ & EF1 & $-1,12$ & A & Improved & $\begin{array}{l}\text { Repairing the performance } \\
\text { of available features on the } \\
\text { Website with trials on } \\
\text { features that will be added } \\
\text { in the future. }\end{array}$ \\
\hline 4 & $\begin{array}{l}\text { Up to date } \\
\text { information on } \\
\text { the website }\end{array}$ & FL2 & $-0,64$ & M & Improved & $\begin{array}{l}\text { Adding useful information } \\
\text { for the customer such as } \\
\text { shopping instruction in the }\end{array}$ \\
\hline
\end{tabular}


International Journal of Entrepreneurship, Business and Creative Economy (IJEBCE), Vol. 2(1), 67-80

E-ServiceQuality Model and Kano Model: An Integration Improvement on Service Quality in

E-Commerce Services

Krishna Kusumahadi, Widya Sastika, Fanni Husnul Hanifa

\begin{tabular}{|c|c|c|c|c|c|c|}
\hline & & & & & & $\begin{array}{l}\text { middle of covid-19 } \\
\text { pandemic, and to conduct a } \\
\text { sale in national holidays or } \\
\text { certain moments. }\end{array}$ \\
\hline 5 & $\begin{array}{l}\text { Immediate } \\
\text { handling and } \\
\text { response } \\
\text { Service }\end{array}$ & СT2 & $-0,84$ & 0 & Improved & $\begin{array}{l}\text { If complaints arise, they } \\
\text { must be quickly responded } \\
\text { to and solved, creating a } \\
\text { standard operating } \\
\text { procedure to decide the } \\
\text { maximum time duration for } \\
\text { responding to complaints. }\end{array}$ \\
\hline 6 & $\begin{array}{l}24 \text { Hour } \\
\text { Complaints } \\
\text { Service }\end{array}$ & CT1 & $-0,45$ & 0 & Improved & $\begin{array}{l}\text { Online complaints must be } \\
\text { made sure to be available } \\
24 \text { hours. Thus, the } \\
\text { customer service can be } \\
\text { contacted whenever, both } \\
\text { through chat and direct } \\
\text { phone call. }\end{array}$ \\
\hline 7 & $\begin{array}{l}\text { Cheap/Free } \\
\text { Delivery Fee }\end{array}$ & CM3 & 0,32 & A & Developed & $\begin{array}{l}\text { Giving more free delivery } \\
\text { fees or delivery fee } \\
\text { discounts events for all } \\
\text { customers. }\end{array}$ \\
\hline 8 & $\begin{array}{l}\text { Correct Product } \\
\text { Guarantee }\end{array}$ & PC3 & $-0,94$ & M & Improved & $\begin{array}{l}\text { Adding sub-menu where } \\
\text { guarantee on buying the } \\
\text { company's products is } \\
\text { explained, and evaluating } \\
\text { policy on an additional fee } \\
\text { for product protection } \\
\text { guarantee. }\end{array}$ \\
\hline
\end{tabular}

\section{CONCLUSION}

Based on the research conducted among 400 respondents, the conclusions to answer problems according to problem formulation within this research are obtained. The conclusions are as follow:

1. There are 21 e-commerce attributes of service that need to be grouped based on the dimension of Efficiency, Fulfillment, Reliability, Privacy, Responsiveness, Compensation, and Contact. There are three attributes of efficiency, three attributes of fulfillment, 3 attributes of reliability, 3 attributes of privacy, 3 attributes of responsiveness, 3 attributes of compensation, and 3 attributes of contact.

2. Based on the result of the Electronic Service Quality questionnaire to learn about Customer Satisfaction Level, there are 14 attributes included in strong attributes and 7 attributes included in weak attributes.

3. Based on the result of service need attributes on Kano Model, there are 9 attributes included inside the must-be category, 9 attributes included inside the one-dimensional category, 3 attributes categorized into the attractive category, and 1 attribute included in the indifferent category.

4. Based on the result of data integration from the Electronic Service Quality and Kano model, there are 8 attributes that become True Customer Needs. Where 7 attributes are recommended to be improved such as Interaction channel (chatbox, et cetera) between the 
International Journal of Entrepreneurship, Business and Creative Economy (IJEBCE), Vol. 2(1), 67-80

E-ServiceQuality Model and Kano Model: An Integration Improvement on Service Quality in

E-Commerce Services

Krishna Kusumahadi, Widya Sastika, Fanni Husnul Hanifa

customer and various customer service (RS 1); Customer Service quickly responds to customer's questions (RS 2); Various features made available on the website (EF 1); Up to date information on the website (product, price, promotion, et cetera) (FL1) ; 24 hours complaint service (CT 1); Immediate handling and response service (CT 2); Correct Product Guarantee (PC 300). And one True Customer Needs attribute which is recommended to be developed is the Cheap/Free Delivery Fee (CM 3).

\section{REFERENCES}

bpkn.go.id. 10 Desember 2020. https://bpkn.go.id/ posts/show/id/2033

Indonesia.go.id. 26 Juni 2020. https://indonesia.go.id/narasi/indonesia-dalamangka/ekonomi/agar-konsumen-tenang-belanja-online

IPrice,“Peta E Commerce Indonesia,” 2020.https://iprice.co.id/insights/mapofecommerce/

Kabarbisnis.com. 14 Desember 2020. https://www.kabarbisnis.com/read/28103647/melonjakkeluhan-konsumen-atas-layanan-e-commerce

Komalasari, Tia Dwitiani. 11 Juni 2020. https://www.pikiran-rakyat.com/ekonomi/pr01399518/belanja-online-meningkat-400-persen-bpkn-masih-banyak-dikeluhkankonsumen?page $=2$

Lee, Y., C., Lin, S. B., \& Wang, L. W. (2011) A New Kano's Evaluation Sheet. The TQM Journal.

Mikulic, J., dan Prebezac, D. (2011). A Critical Review of Techniques for Classifying Quality Attributes

in The Kano's Model. Managing Service Quality. Zagreb: University of Zagreb.

Sirclo.com, “Menilik Tren Perkembangan ECommerce Indonesia di 2020," Solusi Ecommerce, 2020. https://www.sirclo.com/menilik-trenperkembangan-e-commerce-indonesia-di-2020

Tan, K. C., \& Pawitra, T. A. (2001). Integrating SERVQUAL and Kano's model into QFD for service excellence development. Managing Service Quality: An International Journal.

Tjiptono, Fandy \& Gregorius Chandra, (2016). Service, Quality and Satisfaction. Edisi 4, Yogyakarta: ANDI. 